\title{
Impact of biomass in Egypt on climate change
}

\author{
Dalia Adel Nakhla ${ }^{1^{*}}$, Mohamed Galal Hassan², Salah El Haggar ${ }^{3}$ \\ ${ }^{1}$ Environmental Engineering PhD Program, School of Sciences and Engineering, The American University in Cairo, Cairo, Egypt; \\ *Corresponding Author: danakhla@aucegypt.edu \\ ${ }^{2}$ Department of Petroleum Engineering, School of Sciences and Engineering, The American University in Cairo, Cairo, Egypt \\ ${ }^{3}$ Department of Mechanical Engineering, School of Sciences and Engineering, The American University in Cairo, Cairo, Egypt
}

Received 30 November 2012; revised 5 March 2013; accepted 13 March 2013

Copyright (C) 2013 Dalia Adel Nakhla et al. This is an open access article distributed under the Creative Commons Attribution License, which permits unrestricted use, distribution, and reproduction in any medium, provided the original work is properly cited.

\begin{abstract}
Egypt is one of the most vulnerable countries to climate change due to the expected detrimental impacts on coastal zones, agriculture, water security as well as indirect social and health impacts. Egypt is responsible for $0.57 \%$ of the global greenhouse gas (GHG) emissions. Although Egypt is a non-annex I country not requiring any specific emission reduction or limitation targets under the Kyoto protocol, its National plans have included mitigation measures to reduce its greenhouse gases. The main sectors contributing to climate change in Egypt are energy, industry, agriculture and waste.
\end{abstract}

Waste, on the other hand, has been accumulating in the streets of Egypt and along its water banks causing considerable air, soil and water pollution and indirect detrimental health impacts. However, this waste which is composed of organic municipal waste, agricultural residues, agro-industrial waste, animal manure and sewage sludge are valuable biomass resources. Utilizing the waste resources of Egypt especially the biomass or the organic component of this waste will not only solve some of the pressing economic needs of Egypt such as animal fodder, fertilizer and fuel but will also alleviate environmental burdens through decreasing air pollution and greenhouse gas emissions in the sector of waste as well as those of energy, industry and agriculture. This paper quantifies the biomass resources in Egypt generated from different waste resources. Then it demonstrates the efforts that Egypt made to contribute to global greenhouse gas emissions reductions through the Kyoto Protocol's clean development mechanism (CDM). The projects in the waste sector already established in Egypt and approved as
CDM projects are listed, which are related to waste management facilities and those which are waste to energy projects. Finally, a list of mitigation projects as proposed by the Egyptian government to decrease GHGs as related to the waste sector are enumerated.

Keywords: Waste; Climate Change; Biomass; Egypt

\section{INTRODUCTION}

\subsection{Climate Change Issues in Egypt}

Climate change is one of the most pressing environmental problems that the world is currently facing. Egypt is one of the countries expecting to face damaging effects due to climate change, although its contribution to the global greenhouse gas (GHG) emissions is $0.57 \%$ [1] and despite that fact that it is considered a non-annex I country not requiring any specific emission reduction or limitation targets under the Kyoto protocol [2]. Nevertheless, Egypt has included in its National plans mitigation measures to reduce greenhouse gases with regards to the main sectors contributing to climate change which are energy, industry, agriculture and waste [2]. Table 1 shows the trend in GHG emissions in Egypt in the different sectors as calculated by Climate Change Central Department of the Egyptian Environmental Affairs Agency (EEAA) from year 2000 until year 2010. These calculations were based on emission increase rate of $5.1 \%$ and population increase rate of $1.7 \%-2.3 \%$.

Emissions from the energy sector are attributed to fuel combustion in the different sectors (industry, transportation, agriculture, residential and commercial, electricity generation and petroleum production and industries) and fugitive fuel emissions. Industrial emissions are associated with heavy industries such as cement and iron and steel production. Agricultural emissions are mainly those 
Table 1. Estimated GHG inventory in Egypt in million tonnes Eq. $\mathrm{CO}_{2}[3]$.

\begin{tabular}{ccccccc}
\hline Indicators & 2000 & 2002 & 2004 & 2006 & 2008 & 2010 \\
\hline $\begin{array}{c}\text { Total GHG } \\
\text { Emission }\end{array}$ & 193.3 & 208.03 & 212.6 & 219.3 & 288.4 & 318.2 \\
$\begin{array}{c}\text { GHG Emission/ } \\
\text { Energy Sector }\end{array}$ & 88.91 & 95.69 & 97.79 & 100.87 & 132.66 & 146.37 \\
$\begin{array}{c}\text { GHG Emission/ } \\
\text { Transport Sector }\end{array}$ & 27.44 & 29.54 & 30.18 & 31.14 & 40.95 & 45.18 \\
$\begin{array}{c}\text { GHG Emission/ } \\
\text { Industrial Sector } \\
\text { GHG Emission/ }\end{array}$ & 27.83 & 29.95 & 30.61 & 31.57 & 41.5 & 45.82 \\
$\begin{array}{c}\text { Agricultural Sector } \\
\text { GHG Emission/ } \\
\text { Waste Sector }\end{array}$ & 17.39 & 18.72 & 19.13 & 19.73 & 25.95 & 28.63 \\
\hline
\end{tabular}

from enteric fermentation of livestock, manure management, rice cultivation, agricultural soils and field burning of agricultural residues. Finally, GHG emissions associated with waste include those from solid waste disposal sites and wastewater handling and waste incineration [2].

Waste has been and is still currently considered as a burden to the Egyptian environment and economy while it is actually a resource that has not been exploited to a maximum benefit. Egyptian authorities including the relevant ministries and concerned governorates have developed a number of plans and programs to improve waste management including reuse and recycling initiatives. However, a number of obstacles hindered the success of these efforts.

Utilizing the waste resources of Egypt especially the biomass or the organic component of this waste will not only solve some of the pressing economic needs of Egypt such as animal fodder, fertilizer and fuel but will also alleviate environmental burdens through decreasing air pollution and greenhouse gas emissions in the sector of waste as well as those of energy, industry and agriculture.

\subsection{Waste Management in Egypt}

Currently, tons of waste or biomass resources are accumulating on the streets and canals of Egypt causing detrimental environmental, economical and health impacts and contributing to the share of GHG emissions.

Biomass resources from waste generation whether agricultural, industrial or municipal can contribute to the energy budget of Egypt by providing carbon neutral fuel and power and at the same time relieving the environment from the harmful impacts of illegal dumping and burning of these valuable wastes. It could also be used to produce organic fodder and fertilizer to stop the use of chemical fertilizers.

The biomass energy mine could become an environmental landmine if not properly managed. Agricultural residues such as rice straw, for example, has caused environmental degradation to air quality of Cairo and the Delta governorates contributing to the Black Cloud Phenomenon. Since Egypt's rice plantation is among the highest in the world, 4.0 million tons of wastes are left behind annually. Some residues are used to feed animals or recycled, yet open burning remains the most widespread technique of disposal. Such practice, which is only one of many other open burning activities, deteriorates air quality, acts as the potential risk of developing serious health problems (due to the emission of carbon monoxide and other toxic emissions) and consequently, poses potential economic threats.

Landfills are also in use, but no specific regulations are available for monitoring them [4]. Open dumping of the organic content of the waste in landfills, therefore, results in the self ignition of the waste piles, leading to fire hazards and air pollution. These piles are also attracttive for flies, mosquitoes and rodents which pose serious health hazards to communities' health and safety.

Organic wastes are rarely recycled, with the exception of some informal activities or some research driven recycling projects. Some such informal practices include feeding organic waste to home animals bred by garbage collectors [4].

The World Bank's estimate of the mean cost of environmental degradation from poor waste management in Egypt, reported to currently go up to $0.2 \%$ of the GDP [5].

\subsection{Objective}

The objective of this paper is to identify and quantify the potential reductions in GHG emissions due to the reuse of the generated biomass waste resources of Egypt to produce fodder, fertilizer and fuel.

\section{BIOMASS RESOURCES AND CURRENT CONDITIONS}

Waste biomass in Egypt is generated from the following sources:

- Municipal solid waste;

- Agricultural residues (crop residues);

- Agro-industrial by-products (e.g. rice husk, bagasse);

- Animal and poultry by-products (dung);

- Sewage sludge;

- Forest residues;

- Exotic plants (water hyacinth, reeds, etc.).

The total amount of municipal solid waste generated from Egypt's governorates in 2010 is estimated as 19.7 million ton/year [6]. According to Sweepnet [6], the collection coverage of the municipal solid waste in rural areas ranges from $0 \%-35 \%$ and in urban areas $40 \%$ $90 \%$. As for the final destination, $9 \%$ of the municipal 
solid waste is currently composted, $2.5 \%$ are recycled, 5\% land filled and $83.5 \%$ are open dumped [6]. Egypt suffers from low waste collection efficiency varying from $35 \%$ in rural areas to $77 \%$ in large urban centers [6]. Municipal solid waste did not represent a problem in Egypt's rural areas, until the introduction and rise of artificially synthesized materials that are not biodegradable [7].

As for quantities of agricultural waste according to the Agricultural Waste Recycling Unit (AWRU) of the Ministry of State for Environmental Affairs (MSEA) in 2005 reaches 31 million ton/year. Hamdy [8] mentioned that about $52 \%$ of the agricultural residues are burnt directly on the fields or in inefficient burners (less than $10 \%$ efficiency) in small villages, $30 \%$ is used for animal feeding and the rest (18\%) is used as fertilizer.

Agro-industrial waste such as bagasse, resulting from sugar cane after the extraction of juice, amounts to about 4.7 million tons per year [9]. Most of the bagasse is used for heat/electricity generation in the sugar mills with very poor efficiency and emitting black smoke. Rice husk, produced in the rice mills when the brown rice is husked to produce white rice, is estimated to be about 1.6 million tons in 2004 [9]. The husk is partly reused by rice mills as a source of energy for the milling process, and is partly sold as animal feed.

The main sources of manure in Egypt are cow and buffalo farms, as well as poultry farms. The amount of manure generated by the different animals in Egypt's governorates is estimated by 11 million tons [9]. As for the poultry droppings, it is estimated to be in the range of 2.3 million tons per year [9]. About $60 \%$ of the cattle wastes (buffalo and cows) are used as fuel by direct burning in low efficiency burners (less than 10\%); another $20 \%$ of the animal wastes is used as organic fertilizer, and the rest is lost in handling.

According to the Holding Company for Water and Wastewater (HCWW), the National Organization for Potable Water \& Sanitary Drainage (NOPWSD), the total number of wastewater treatment plants in Egypt is 303 treating $11.85 \times 10^{6} \mathrm{~m}^{3} /$ day of wastewater. The corresponding sewage sludge production was estimated to 5800 tons/day with a sludge production rate of 0.48 $\mathrm{kg} / \mathrm{m}^{3}$ of treated wastewater [10].

The most common sewage sludge treatment method used in most WWTPs is thickening and dewatering of sludge then storage and finally land application. Only in Al Gabel Asfer WWTP, is the largest in Egypt, anaerobic digestion technology for sludge stabilization and power generation has been applied. Windrow composting is another common treatment method of sewage sludge applied in WWTPs like the Al Berka WWTP in Cairo and the $(9 \mathrm{~N})$ site in Alexandria.

The Ministry of State of Environmental Affairs in co- operation with the Ministry of Agriculture and Ministry of Housing implemented the National Program for Treated Sanitary Drainage Water Safe Use in Cultivating Timbers. About 15,800 feddan were planted with wood trees using treated wastewater. It was estimated that the amount of residues generated per feddan to be about 25 tons mainly composed of wood chips and forest residues.

Water hyacinth and reeds are the most abundant exotic plants in Egypt. Water hyacinth are found in irrigation canals and drains in the Delta region and along the Nile Valley. It was estimated by El Hinnawi [9], that water hyacinth annual yield is 400,000 tons.

Emissions resulting from the treatment and disposal of wastes include solid waste disposal on land (landfills), wastewater treatment, and waste incineration. The categories evaluated are methane $\left(\mathrm{CH}_{4}\right)$ emissions from solid waste disposal on land, $\mathrm{CH}_{4}$ and $\mathrm{N}_{2} \mathrm{O}$ emissions from wastewater treatment, and $\mathrm{CO}_{2}, \mathrm{CH}_{4}$, and $\mathrm{N}_{2} \mathrm{O}$ emissions from waste incineration [11]. However, the most important gas produced in the waste category is methane as approximately 5 - 20 percent of annual global anthropogenic $\mathrm{CH}_{4}$ produced and released into the atmosphere from the anaerobic decomposition of waste.

\section{EGYPT AND STEPS TAKEN TO RECTIFY ITS GHGS}

Egypt has shown efforts to contribute to global greenhouse gas emissions reductions through the Kyoto Protocol's Clean Development Mechanism (CDM).

In 1992, Egypt established a climate change unit in the Egyptian Environmental Affairs Agency as the focal point of the United Nations Framework Convention on Climate Change (UNFCCC) and Kyoto Protocol with the aim of coordinating and integrating all national and international activities relevant to climate change [12]. The unit became the Central Department for Climate Change. Then in 1997, Egypt established a National Committee of Climate Change to supervise the climate change policies. Moreover, the Egyptian Environmental Affairs Agency (EEAA) has assigned the Egypt Council for the CDM as the Designated National Authority (DNA) to manage the CDM activities and approve suitable projects [12].

On the sectoral level, two committees in Ministry Water Resources and Irrigation were established. In addition, a climate change information centre was formulated for Agriculture Sector and an adaptation program in Agriculture Sustainable Development Strategy up to 2030 was conducted [2].

The Ministry of Environment along with the relevant ministries had established efforts to mitigate GHGs in the different sectors as follows [12]:

1) The energy sector; Egypt's Strategy for Energy Supply and Use integrated the main policies and meas- 
ures that could meet the longer term challenges including security of energy supplies; sustainability of current energy usage; and the abatement of GHG emissions. It was proposed that reductions of GHG emissions from the energy sector could be achieved through including renewable energy; energy efficiency; lower carbon fuels; nuclear power; and improved transportation fleets;

2) The industrial sector; a number of policies and measures have been adapted to decrease GHG emissions per unit of product in industrial processes and product use (excluding those related to energy). However, barriers such as need of information about GHG emissions reduction opportunities; long payback periods on investments; and lack of access to investment capital and/ or high interest rate on investments, hinder the achievement of considerable GHG emissions reduction;

3) The transport sector; The Ministry of Transport adopted a strategy to improve public transport; improve energy efficiency; switching of fuel; the development and use of new technologies; the development of rail transport and new methods for freight transport; the development of power train technologies; shifting from diesel to electrified railways; and the development and use of fuel cells technology;

4) The agricultural sector; national efforts for GHG emission reduction included paddy rice cultivation, livestock production, soil management, improvement of feeding patterns and technologies to enhance veterinary care, and development of breeding programs for livestock production; an sustaining rice cultivated areas under 1.47 million acres, then reducing these to 1.26 million acres by 2017 while switching from conventional cultivars to short duration cultivar and applying intermittent irrigation;

5) The waste sector; several plans and programs have been developed to improve the process of collection, reuse and recycling of waste.

\section{EFFORS TO REDUCE GHGS IN THE WASTE SECTOR IN EGYPT}

Egypt has currently a number of projects registered with the Executive Board and a number at the process of validation. Furthermore, there are several other projects that have been accepted by the Egyptian DNA but have not received final approval yet.

The projects in the waste sector already established in Egypt and approved as CDM (Clean Development Mechanism) projects are listed in Table 2 along with its Certified Emission Reductions (CERs) or carbon credits. A number of these projects are related to waste management facilities and the others are waste to energy projects.

However, there are also a number of projects that are not yet recognized as CDM projects yet but have proven-
Table 2. Egypt CDM projects related to biomass [13].

\begin{tabular}{|c|c|c|}
\hline Project & CERS & DNA Status \\
\hline \multicolumn{3}{|c|}{ Waste Management Projects } \\
\hline $\begin{array}{l}\text { Onyx Alexandria Landfill Gas } \\
\text { Capture and Flaring Project }\end{array}$ & 370,903 & Approved \\
\hline $\begin{array}{l}\text { Land Filling and Processing } \\
\text { Services for Southern Zone } \\
\text { in Cairo }\end{array}$ & 76,652 & Approved \\
\hline $\begin{array}{l}\text { Abu Zaabal Landfill Gas } \\
\text { Recovery and } \\
\text { Flaring/Destruction }\end{array}$ & 94,819 & Approved \\
\hline $\begin{array}{l}\text { Methane Capture and Flaring } \\
\text { in Belbis Landfill }\end{array}$ & $\begin{array}{c}\text { 46,528 } \\
\text { (Total over } 10 \text { Years) }\end{array}$ & Accepted \\
\hline $\begin{array}{l}\text { Methane Reduction by } \\
\text { Composting in Khatatba Landfill }\end{array}$ & 7312 & Accepted \\
\hline $\begin{array}{l}\text { Capture of Landfill Gas } \\
\text { (LFG) from the } \\
\text { Sanitary Landfill }\end{array}$ & 22,000 & Accepted \\
\hline $\begin{array}{l}\text { Landfill Gas Capturing and } \\
\text { Flaring in El Kattamia Landfill }\end{array}$ & 100,000 & Accepted \\
\hline $\begin{array}{l}\text { Biogas Generation from Waste } \\
\text { Water Treatment and Utilization } \\
\text { for Heat Generation by } \\
\text { Indorama Organics (Egypt) } \\
\text { Co.S.A.E. in Beni Suef, Egypt }\end{array}$ & 20,000 & Accepted \\
\hline $\begin{array}{l}\text { Anaerobic Digestion of } \\
\text { Sludge in El-Gharbia } \\
\text { WWTP-Alexandria } \\
\text { Sewage Company }\end{array}$ & 346,378 & Accepted \\
\hline $\begin{array}{l}\text { Develop Agriculture Wastes } \\
\text { Management for Reducing } \\
\text { Gas Emission }\end{array}$ & 329,000 & Accepted \\
\hline \multicolumn{3}{|c|}{ Waste to Energy Projects } \\
\hline $\begin{array}{l}\text { Emissions Reduction through } \\
\text { Partial Substitution of Fossil } \\
\text { Fuels with Renewable Plantation } \\
\text { Biomass and Biomass Residues } \\
\text { in CEMEX Assuit Cement Plant }\end{array}$ & 204,693 & Approved \\
\hline $\begin{array}{l}\text { Partial Fuel Switching to } \\
\text { Agricultural Wastes \& } \\
\text { Refuse Derived Fuel (RDF) } \\
\text { at Helwan Cement Plant }\end{array}$ & 38,302 & Approved \\
\hline $\begin{array}{l}\text { Partial Fuel Switching to } \\
\text { Agricultural Wastes \& Refuse } \\
\text { Derived Fuel (RDF) at } \\
\text { Kattameya Cement Plant }\end{array}$ & 19,472 & Approved \\
\hline $\begin{array}{l}\text { Fuel Switch from Natural Gas to } \\
\text { Biomass Project in Pepsi Cola } \\
\text { Egypt (6 October Factory) }\end{array}$ & 2585 & Accepted \\
\hline $\begin{array}{c}\text { Fuel Switch from Natural Gas to } \\
\text { Biomass Project in Pepsi Cola } \\
\text { Egypt (Alexandria Factory) }\end{array}$ & 1747.09 & Accepted \\
\hline $\begin{array}{c}\text { Fuel Switch from Natural Gas to } \\
\text { Biomass Project in Pepsi Cola } \\
\text { Egypt (Sohag Factory) }\end{array}$ & 1620.14 & Accepted \\
\hline
\end{tabular}




\begin{tabular}{lll} 
Continued & & \\
\hline $\begin{array}{c}\text { Fuel Switch from Natural Gas to } \\
\text { Biomass Project in Pepsi Cola } \\
\text { Egypt (Port Said Factory) }\end{array}$ & 3662.21 & Accepted \\
Fuel Switch from Natural & 3662.21 & Accepted \\
$\quad$ Gas to Biomass & & \\
Biomass Bases Steam and & & Accepted \\
$\begin{array}{l}\text { Power Generation by Indorama } \\
\text { Organics (Egypt) Co.S.A.E. in } \\
\text { Beni Suef, Egypt }\end{array}$ & 70,000 & \\
CO & & \\
Through Partial Substitution of & 640,646 & Accepted \\
$\begin{array}{l}\text { Fossil Fuel by Biomass (Rice } \\
\text { Straw) from Agricultural Waste }\end{array}$ & & \\
Partial Fuel Switching to & & Pipeline \\
Agricultural Wastes, Sewage & 67,273 & \\
$\begin{array}{l}\text { Sludge \& Refused Derived Fuel } \\
\text { (RDF) at Arabian Cement Plant }\end{array}$ & &
\end{tabular}

to be very successful in Egypt in terms of sustainable management of biomass. These are compost plants of organic municipal solid waste and in some cases agricultural waste. Aerobic composting is known to treat organic waste while minimizing the potential of producing methane. There are more than 39 compost plants in Egypt distributed among 25 governorates, mostly publically owned but leased to be operated by the private sector [14].

The compost plant located within the "Land Filling and Processing Services for Southern Zone in Cairo", that is mentioned in Table 2, is the first compost plant to be approved as a CDM project in Egypt. It is owned by a private contractor ECARU [15].

Moreover, EEAA is working on a project of "Bioenergy for Sustainable Rural Development" as a joint program with Global Environment Facility (GEF) and the United Nations Development Program (UNDP) [15]. The initial output of this project was a number of household biogas units producing biogas from animal waste. It is estimated that these unit will cause an emission reduction estimate for each household biogas unit is in the order of 0.85 tonnes $\mathrm{CO}_{2}$ per year [16]. The project also plans to promote the following:

- Poultry farm units based on poultry litter;

- Gasification units generating gas from agricultural waste;

- Gasification units generating electricity from rice straw.

EEAA has also contracted companies to collect and process more than 500,000 tons per year of agricultural solid waste, mostly rice straw to convert it into compost and animal fodder. These projects are not yet recognized as CDM projects as those of coverying agricultural waste to refuse derived fuel, although they have a significant contribution to solving the issue of the rice straw burning in Egypt.

\section{PROPOSED ACTIONS TO FURTHER REDUCE GHGS THROUGH BIOMASS REUSE}

Egypt has realized that mitigating global warming and climate change can only be achieved through reduction of GHG emissions. The mitigation measures and policies proposed to be implemented in the different sectors were based on the country's national plans to promote sustainable development in Egypt [2].

In the waste sector, mitigation options were investigated for the solid waste differently from those of the wastewater. Solid waste management required the establishment of administrative mechanisms as well as employment of experts to assist in location of landfills and provision of support to private sector involved in waste collection and recycling. For the wastewater, measures included maintenance of existing facilities, as well as organization of the institutional set-up of the concerned entities [2].

Egypt Second National Communication Report has proposed a number of mitigation measures in the waste sector based on six main criteria including investment costs, payback periods, GHGs emission reductions potentials, duration of implementation, priority in national strategies/programs and contribution to sustainable development [2]. A number of scenarios for waste and wastewater sectors causing lowest GHG emitting scenario were selected for implementation during the period 2009 to 2025 as shown in Tables 3 and 4.

Table 3. Summary of identified mitigation measures for solid waste [2].

\begin{tabular}{|c|c|c|}
\hline Mitigation Measure & $\begin{array}{l}\text { Emission Reduction } \\
\text { Potential (ton } \mathrm{CO}_{2} \mathrm{e} \\
\text { per ton } \mathrm{MSW} \text { ) }\end{array}$ & $\begin{array}{l}\text { Investment Cost } \\
\text { (US \$/ton MSW) }\end{array}$ \\
\hline $\begin{array}{l}\text { Composting and } \\
\text { Recycling Facilities }\end{array}$ & 0.38 & 0.92 \\
\hline $\begin{array}{l}\text { Refuse Derived Fuel } \\
\text { (RDF) with Electricity } \\
\text { Generation only, } \\
\text { Composting and } \\
\text { Recycling }\end{array}$ & $<0.3$ & 2.07 \\
\hline $\begin{array}{l}\text { Refuse Derived Fuel (RDF) } \\
\text { with Substitution in } \\
\text { Cement Kilns, } \\
\text { Composting and } \\
\text { Recycling Facilities }\end{array}$ & $<0.3$ & 1.97 \\
\hline $\begin{array}{l}\text { Anaerobic Digestion with } \\
\text { Recycling (Flaring Biogas) }\end{array}$ & 0.342 & 12.16 \\
\hline $\begin{array}{l}\text { Anaerobic Digestion Wit } \\
\text { Recycling Facilities (with } \\
\text { Electricity Generation) }\end{array}$ & 0.547 & 16.16 \\
\hline
\end{tabular}


Table 4. Summary of identified mitigation measures for wastewater [2].

\begin{tabular}{|c|c|c|}
\hline Mitigation Measure & $\begin{array}{c}\text { Emission Reduction } \\
\text { Potential }\left(\mathrm{kg} \mathrm{CO}_{2} \mathrm{e} /\right. \\
\left.\mathrm{m}^{3} \mathrm{WW}\right)\end{array}$ & $\begin{array}{l}\text { Investment Cost } \\
\text { (US } \$ / \mathrm{m}^{3} \mathrm{WW} \text { ) }\end{array}$ \\
\hline \multicolumn{3}{|c|}{ Untreated Domestic Wastewater in Current Practice } \\
\hline $\begin{array}{l}\text { Aerobic Treatment of } \\
\text { Wastewater and Aerobic } \\
\text { Treatment of Sludge } \\
\text { through Composting }\end{array}$ & 0.29 & $\begin{array}{l}\text { Shallow Ponds: } 0.015 \\
\text { Aerobic WWTP: } 0.050\end{array}$ \\
\hline $\begin{array}{l}\text { Aerobic Treatment of } \\
\text { Wastewater and } \\
\text { Combustion of Sludge } \\
\text { in Cement Kiln }\end{array}$ & 2.25 & $\begin{array}{l}\text { Shallow Ponds: } 0.014 \\
\text { Aerobic WWTP: } 0.050\end{array}$ \\
\hline $\begin{array}{c}\text { Aerobic Treatment of } \\
\text { Wastewater and Treatment } \\
\text { of Sludge in Anaerobic } \\
\text { System of Biogas Flaring }\end{array}$ & 2.55 & $\begin{array}{l}\text { Shallow Ponds: } 0.134 \\
\text { Aerobic WWTP: } 0.170\end{array}$ \\
\hline $\begin{array}{c}\text { Aerobic Treatment of } \\
\text { Wastewater and Treatment } \\
\text { of Sludge in Anaerobic } \\
\text { System with Electricity } \\
\text { Generation }\end{array}$ & 2.79 & $\begin{array}{l}\text { Shallow Ponds: } 0.154 \\
\text { Aerobic WWTP: } 0.190\end{array}$ \\
\hline
\end{tabular}

Anaerobically Treated Domestic Wastewater without Biogas Recovery in Current Practice

\begin{tabular}{|c|c|c|}
\hline $\begin{array}{l}\text { Aerobic Treatment of } \\
\text { Wastewater and Aerobic } \\
\text { Treatment of Sludge } \\
\text { through Composting }\end{array}$ & 1.72 & $\begin{array}{l}\text { Shallow Ponds: } 0.015 \\
\text { Aerobic WWTP: } 0.050\end{array}$ \\
\hline $\begin{array}{l}\text { Aerobic Treatment } \\
\text { of Wastewater and } \\
\text { Combustion of Sludge } \\
\text { in Cement Kiln }\end{array}$ & 3.68 & $\begin{array}{l}\text { Shallow Ponds: } 0.014 \\
\text { Aerobic WWTP: } 0.050\end{array}$ \\
\hline $\begin{array}{l}\text { Aerobic Treatment of } \\
\text { Wastewater and Treatment } \\
\text { of Sludge in Anaerobic } \\
\text { System with Biogas Flaring }\end{array}$ & 1.84 & $\begin{array}{l}\text { Shallow Ponds: } 0.134 \\
\text { Aerobic WWTP: } 0.170\end{array}$ \\
\hline $\begin{array}{c}\text { Aerobic Treatment of } \\
\text { Wastewater and Treatment } \\
\text { of Sludge in Anaerobic } \\
\text { System with Electricity } \\
\text { Generation }\end{array}$ & 4.22 & $\begin{array}{l}\text { Shallow Ponds: } 0.154 \\
\text { Aerobic WWTP: } 0.190\end{array}$ \\
\hline \multicolumn{3}{|c|}{ Untreated Industrial Wastewater in Current Practice } \\
\hline $\begin{array}{l}\text { Aerobic Treatment } \\
\text { of Wastewater and } \\
\text { Combustion of Sludge } \\
\text { in Cement Kilns }\end{array}$ & 4.09 & $\begin{array}{c}\text { Shallow Ponds: } 0.014 \\
\text { Aerobic WWTP: } 0.050\end{array}$ \\
\hline $\begin{array}{l}\text { Aerobic Treatment of } \\
\text { Wastewater and Treatment } \\
\text { of Sludge in Anaerobic } \\
\text { System with Biogas Flaring }\end{array}$ & 2.46 & $\begin{array}{l}\text { Shallow Ponds: } 0.134 \\
\text { Aerobic WWTP: } 0.170\end{array}$ \\
\hline $\begin{array}{c}\text { Aerobic Treatment of } \\
\text { Wastewater and Treatment } \\
\text { of Sludge in Anaerobic } \\
\text { System with Electricity } \\
\text { Generation }\end{array}$ & 2.70 & $\begin{array}{l}\text { Shallow Ponds: } 0.154 \\
\text { Aerobic WWTP: } 0.190\end{array}$ \\
\hline
\end{tabular}

\section{Continued}

Anaerobic Treatment of
Wastewater and Treatment
of Sludge in Anaerobic
System with Biogas Flaring

\section{CONCLUSION}

Although the road to reduction of GHG emissions and combating climate change with regards to management of the waste biomass resources is through a number of mitigation measures or projects, still some barriers hinder the progress of these proposals. On the top of the list of barriers is the weak enforcement of the existing laws and regulations concerned with waste management [2]. Other barriers that face the utilization of waste include

- Technical barriers due to lack of local expertise, manufacturers, and agents, as well as lack of maintenance and standardization of equipment;

- Institutional and policy barriers as development of the proposed projects requires decentralized approaches and national-level coordination as well as an effective institution to promote waste to energy technologies;

- Economic and financial barriers as a supportive financial environment are essential to support the development of small and medium decentralized projects. Therefore, financial institutions/agencies are needed in handling such small capital requirements. However, significant dependence on external financial support (such as grants and concessionary loans) complicates the planning process and slows down implementation;

- Awareness and information barriers due to lack of reliable information on biomass resources at the local level and the economic benefits of reuse and recycling of waste.

Market barriers as the existing policies and plans in the past have been in favor of large conventional technologies. The pricing policies should take into account the high environmental costs of conventional versus non conventional approaches.

\section{REFERENCES}

[1] Selim, T.H. (2009) Egypt's carbon emissions and the kyoto protocol. Egypt, energy and the environment. Adonis \& Abbey Ltd.

[2] United Nations Framework Convention on Climate Change (2010) Egypt second national communication.

[3] Egyptian Environmental Affairs Agency (2012) Estimat- 
ed GHG inventory in Egypt.

www.eeaa.gov.eg/english/reports/CC/Estimated\%20GHG \%20Inventory\%20in\%20Egypt.pdf

[4] American Chamber of Commerce in Egypt (2000) Solid waste management in Egypt.

[5] The Ministry of Local Development, United Nations Development Programme and the World Bank (2010) Consultancy for up stream poverty and social impact analysis for Egypt's solid waste management reform.

[6] The Regional Solid Waste Exchange of Information and Expertise Network in Mashreq and Maghreb Countries (Sweepnet) (2010) Country report on the solid waste management in Egypt.

[7] Environmental Quality International (2005) Alternative methods for solid waste management and treatment and disposal of wastewater.

[8] Hamdy, Y.A. (1998) The current situation of Egyptian agricultural wastes. Proceedings of Anaerobic Treatment of Solid Wastes Workshop, Mansoura, 4 May 1998, 1-5.

[9] El-Hinnawi, E. (2006) Renewable energy sector in Egypt, bioenergy industry, a study carried out for Industrial MoDernization Program (IMP) by Energy Research Center (ERC) Faculty of Engineering, Cairo University, Project: IMC/PS_217.

[10] Ghazy, M., Dockhorn, T. and Dichtl, N. (2009) Sewage sludge management in Egypt: Current status and perspectives towards a sustainable agricultural use. World Academy of Science, Engineering and Technology, 57, 299.

[11] Integral Environmental and GIS Solutions (2008) Final inventory report: Second national communication project waste section (CRF Sector 6).

[12] Egyptian Environmental Affairs Agency and United Nations Framework Convention on Climate Change (2010) Egypt National Environmental, Economic and Development Study (NEEDS) for climate change.

[13] Egyptian Environmental Affairs Agency (2012) Egyptian CDM project portfolio.

http://www.eeaa.gov.eg/english/reports/CC/doc/Total\%20 CDM\%20Project\%20Portofolio\%20Public\%20May\%202 012.pdf

[14] Egyptian Environmental Affairs Agency and United States Agency for International Development (2003) Evaluation of composting facilities in Egypt.

[15] United Nations Framework Convention on Climate Change (2006) Clean Development Mechanism project design form (CDM-PDD) Version 03.

[16] United Nations Development Programme (UNDP) (2013) Evaluation of UNDP/GEF project: Bioenergy for sustainable rural development. 